\title{
ROBERT HENRI, WALT WHITMAN, AND THE AMERICAN ARTIST
}

\author{
Ruth L. BoHaN
}

"I LOVE WALT, and I follow everything that is written about him," painter Robert Henri exclaimed at his first meeting with anarchist Emma Goldman, herself an ardent consumer of Whitman's verse. ${ }^{1}$ A committed and highly respected teacher of some of the country's most important early twentieth-century artists, Henri articulated a significant place for Whitman within the country's expanding arts community. Whitman's non-elitist, activist posture and his enthusiastic engagement with even the most mundane elements of his urban milieu offered a refreshingly new and democratic perspective far removed from the staid, impersonal standards mandated by the Academy. Particularly important were Whitman's celebration of the self, personality, and the bond between the individual and the community. In striking opposition to the high moral expectations that circulated around nineteenth-century notions of character, the emphasis on personality - what Whitman lauded as "the great pride of man in himself" - shifted the dynamic inward toward the self. $^{2}$ In 1896, four years after Whitman's death, the naturalist John Burroughs, a member of Whitman's inner circle, boldly characterized the poet as "a new type, rising out of new conditions ... the new man in the new world." " Henri commenced his career in Philadelphia with words like Burroughs's echoing in his ear and throughout his thirtyyear career achieved widespread recognition as a forceful and dynamic interpreter of the creative potential of Whitman's verse for members of the American arts community. Whether in the classroom, in his writings, or in his innovative contributions to the exhibition practices of the day, Henri nurtured and inspired a broad range of artists, many of whom are recognized today for their innovative and provocative contributions to American modernism. ${ }^{4}$

Born in Cincinnati, Henri was raised on the Nebraska frontier where he combined an active outdoor life with a passion for books. But when his father, a gambler and cattleman, shot one of his employees in self-defense, Henri's western life came to an abrupt and untimely end. It was at this point that the Nebraska-bred Robert Henry Cozad reinvented himself as Robert Earle Henri. "Names are the turning point of who shall be master," Whitman advised, and, like Henri, he 
had enacted his own audacious act of self-mastery at the outset of his poetic career by changing his name from the formal "Walter Whitman, Jr." to the more personable and informal "Walt Whitman."5 Henri's act of self-naming signified a similarly dramatic rupture with the past

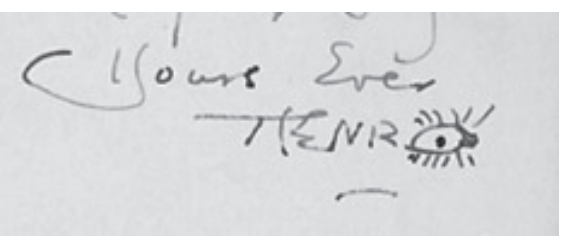

Figure 1. Detail of illustrated letter from Robert Henri to Dolly Sloan, January 12, 1908. John Sloan Manuscript Collection, Delaware Art Museum. Gift of Helen Farr Sloan, 1978. and a foreshadowing of his artistic future. The name "Henri" constituted a reformulation of his own middle name, but with the French spelling of his ancestors. Although he would later spend considerable time abroad, Henri rejected the name's French pronunciation, preferring the more individualistic and conspicuously American "Hen-rye." The aspiring artist in Henri also recognized the name's value as a graphic reinforcement of the act of seeing, for embedded in this Anglo-French hybrid is a homophonic pun on the English word "eye," which Henri wittily acknowledged with his signature on a letter to the wife of his friend John Sloan (Figure 1).

Three years into his new identity, Henri enrolled as a student at the Pennsylvania Academy of the Fine Arts. Too late to study with Thomas Eakins, whose resignation eight months earlier had deprived the school of an ardent Whitman supporter, Henri, like other artists of his generation, first came to appreciate Whitman's importance both for himself and for American art generally during an extended period of study and travel in Europe. Whitman's reputation in France and throughout much of Western Europe was considerably stronger than in the United States at this time and was already attracting the attention of a growing cadre of writers, artists, and critics. ${ }^{7}$ Henri was initially drawn more to Emerson than Whitman when he arrived to study at the Académie Julian in September 1888, but spirited conversations with the Canadian artist Ernest Thompson Seton, a fellow student at the Académie, helped shift his attention toward Whitman. The two painted together in the forests near Fontainebleau where they indulged their fondness for the French Barbizon artist, Jean-François Millet, a favorite also of Whitman, and explored their love of nature and their growing interest in matters of the self. ${ }^{8}$

Henri's interest in Whitman intensified following his return to Philadelphia in late 1891. The poet, who lived out the last twenty years of his life just across the Delaware River in Camden, New Jersey, was in failing health and would die the following March. ${ }^{9}$ When he died, the local press devoted dozens of column inches to lengthy assessments of his poetry, his life, and his "magnificent personality." 10 National 
and international publications soon followed with their own glowing tributes to the poet. With only slight exaggeration Whitman scholar Gay Wilson Allen lamented that "in his death Whitman received more newspaper space than he had during his whole lifetime." 11 At the cemetery a crowd of between three and four thousand listened respectfully to the remarks of the acclaimed inspirational speaker, Colonel Robert G. Ingersoll, and members of Whitman's inner circle who lauded the poet for his humanitarianism, his songs of death and immortality, and his impassioned sympathy for the common and the everyday. ${ }^{12}$

In the months following Whitman's death, Henri strengthened his commitment to the Camden bard through friendships and professional contacts within the local arts community. At the Philadelphia School of Design for Women, where Henri launched his teaching career, two of his colleagues, Henry McCarter and Samuel Murray, both former Eakins students, were Whitman enthusiasts. ${ }^{13}$ Henri was also friends with the quixotic poet, playwright, and critic Sadakichi Hartmann, who in 1895 published Conversations with Walt Whitman, a memoir detailing his many personal encounters with the man he enthusiastically lauded as "the most American intellectual individuality these States have hitherto produced." 14 But it was Henri's friendship with John Sloan, which commenced over a conversation about Whitman at the studio of sculptor Charles Grafly, that generated the most enduring and rewarding of his involvements with Whitman's Philadelphia supporters. Sloan later confessed, "Henri was my father in Art, I got my Whitman through him" (qtd. in Kwiat, 620). ${ }^{15}$

The year following their introduction Henri began hosting weekly gatherings at his studio at 806 Walnut Street. The gatherings included lively discussions of art, music, literature, politics, and the role of the artist in society. Besides Whitman, the group pondered the writings of Edward Bellamy, Ralph Waldo Emerson, William Morris Hunt, John Ruskin, Émile Zola, Leo Tolstoy, and Henrik Ibsen. Sloan recalled in particular the comprehensive way Whitman energized the group's commitment to yoking their art with the quotidian experiences of their lives. He hailed the poet as "a very important influence on our thinking in the '90s," a "catalyst," whose "stimulating poetic point of view" helped members of the group translate the seemingly mundane experiences around them into art. ${ }^{16}$ In addition to Sloan, the group included a number of newspaper illustrators, including William Glackens, Everett Shinn, and George Luks (all later members of the influential American art group known as The Eight), Edward Davis (father of artist Stuart Davis), and sculptors Charles Grafly and A. Stirling Calder.

Henri's Philadelphia gatherings approximated that "close phalanx, ardent, radical and progressive" that Whitman had called for in his address before the Brooklyn Art Union some forty years earlier. ${ }^{17}$ In the 
fledgling American art community of 1850 s New York, Whitman had sought to bolster the standing of artists both individually and as part of what he hoped would be a growing democratic association by urging them to nurture a strong, collective identity. Doing so, he reasoned, would help to keep distracting and uncreative elements at bay, while simultaneously diminishing the lure of Europe. In similar fashion, Henri strengthened the independence and self-esteem of the fledgling artists in his circle, while fostering a lively artistic community where previously there had been none. As Sloan remarked, "it was really Henri's direction that made us paint at all, and paint the life around us. ... I feel certain that the reason our group in Philadelphia became painters is due to Henri." 18

In 1900, Henri moved to New York. Seven months later, he returned to Philadelphia at the invitation of the Philadelphia School of Design for Women to deliver his first public lecture on art. The talk, presented on March 29, 1901, provided Henri with an important public platform from which to disseminate his beliefs on Whitman's importance for current and future generations of American artists. The Philadelphia Press, edited by long-time Whitman supporter Talcott Williams, accorded the lecture prominent billing.

Henri commenced his remarks by distancing himself from one of the mainstays of the nineteenth-century art curriculum and the dominant theme of his own art instruction at the Académie Julian. "The real study of an art student," he cautioned, "is generally missed in the pursuit of technic." Far more crucial for the artist and society generally was the nurturing of the artist's imaginative sense: "The cherishing of his emotions. Never undervaluing them. The pleasure of exclaiming them to others. And an eager search for their clearest expression." Like the narrator in Whitman's short poem "When I Heard the Learn'd Astronomer," Henri stressed the value of the imagination and of empirical observation over the abstract "charts and diagrams" that too often dominated learning in a classroom $(L G, 271)$. "The teacher should be an encourager," he advised, not merely an enforcer of the received codes and expectations of the past: "The reproduction of things is but the idle industry of one who does not value his sensations." Confident of his audience's familiarity with the basic contours of Whitman's life and assured that at least some in the audience had known the poet personally, Henri stressed Whitman's value as a model for young artists. "Walt Whitman was such as I have proposed the real art student should be. His work - nothing greater has been done at any time-is an autobiography - not of haps and mishaps, but of his deepest thoughts, his life indeed." To drive home his point, Henri cited a passage from Whitman's autobiographical essay, "A Backward Glance O'er Travel'd Roads," in which the poet forcefully reiterated the connection between 
his verse and his person: "'Leaves of Grass' indeed (I cannot too often reiterate) has mainly been the outcropping of my own emotional and other personal nature-an attempt, from first to last, to put a person, a human being (myself, in the latter half of the nineteenth century, in America) freely, fully and truly on record." 19

Not cited in the newspaper account but equally important to Henri's pedagogical platform and fully-articulated in "A Backward Glance" was Whitman's emphasis on the importance of personality. With forthright directness, Whitman explained his "ambition to articulate and faithfully express in literary or poetic form, and uncompromisingly, my own physical, emotional, moral, intellectual, and aesthetic Personality, in the midst of, and tallying, the momentous spirit and facts of its immediate days, and of current America." In even stronger language, he announced his intention "to exploit that Personality ... in a far more candid and comprehensive sense than any hitherto poem or book" ( $L G$, 563). ${ }^{20}$ Whitman's dramatic assertion of the value of filtering the sights and sounds of "current America" through the enlarging lens of his own personal identity made a lasting impression on Henri who would make this the cornerstone of his teaching philosophy. As an avid consumer of the expanding literature on Whitman, Henri was well-aware of the strong biographical orientation of much of the early twentieth-century writings on Whitman and of the general fascination with the poet's colorful individuality. ${ }^{21}$ His own inclinations in this regard were reinforced by his acquaintance with Carleton Noyes, a Harvard graduate and instructor of English there who sought out Henri's advice on a book he was writing on the enjoyment of art from a layman's point of view. In 1910 Noyes published An Approach to Walt Whitman, one of the several books of the period to examine Whitman's poetry as a direct manifestation of his life. "The essence of his personality is distilled for us in his poetry," Noyes asserted, "and therein we have the man in his fullest revelation." In a statement which could have been written by Henri himself, Noyes asserted: "The culture for which Whitman pleads is the culture of the personality, the return from external standards and supports to one's own native force and the authority inherent in one's self." 22

To a generation bristling under the restrictive policies of the Academy and confounded by the increasing blandness of corporate America, Whitman's emphasis on the self-affirming power of the individual proved an attractive alternative for artists across the visual spectrum. And although Whitman was neither the first nor the sole voice advocating for greater personal freedom in the arts in the early years of the twentieth century, his presence helped root those ideas in an explicitly American cultural context. ${ }^{23}$ For nearly three decades, Henri channeled Whitman's emphasis on the self, personality, and the 
bond between the individual and the community into a pedagogical practice that attracted many of the country's leading younger artists. First at the Veltin School and later at the New York School of Art, the Henri School, the Art Students League, and the Ferrer Center, Henri encouraged artists to internalize and personalize the lessons of Whitman's verse. Like the poet whose ideas he so vigorously championed, Henri attached little importance to the constricting and often divisive associations that circulated around notions of style and artistic affiliation and focused instead on matters essential to the personal development of each artist individually. As he noted, "I do not teach my students to lean on what I say or what I see. I want them to see for themselves. I want them to be independent." 24

In a major article in The Craftsman, published in 1909, Henri reiterated his commitment to instilling in his students a compelling sense of independence in order to develop "a strong personal art in America." Such an art, he advised, was "not limited to a question of subject or of technique" but called for "a real understanding of the fundamental conditions personal to a country, and then the relation of the individual to these conditions." Henri again cited Whitman as the ideal model for young artists. "Before a man tries to express anything to the world, he must recognize in himself an individual," he wrote, "a new one, very distinct from others. Walt Whitman did this, and that is why I think his name so often comes to me. The one great cry of Whitman was for a man to find himself." ${ }^{25}$ The excited language, first person narration, and rambling presentation that are the hallmarks of Whitman's verse proved especially attractive to a generation of artists eager to distance themselves from the timeworn expectations of their craft, yet largely unsure of how to map a more fulfilling and challenging future. Whether it was the "groups of newly-come immigrants" at the wharves, "the loud laugh of work-people at their meals," or "The prostitute [draggling] her shawl" and the "crowd [who] laugh at her blackguard oaths," Whitman filled his verse with lively first person narratives that enchanted audiences with their variety, humanity, and sense of a life lived to its fullest: "In me the caresser of life wherever moving, / . . Absorbing all to myself and for this song" ( $L G, 42,56,43,40)$.

Whitman's assertive posture of direct urban encounter accorded well with the journalistic experiences of several of Henri's students and quickly became the model for one of the most distinctive tools in Henri's pedagogical arsenal. Henri regularly assigned students to explore the city on foot, recording their experiences in quickly drawn sketches that would be reworked into more detailed paintings during each week's composition class. He once described the "sketch hunter" as one who "moves through life as he finds it, not passing negligently the things he loves, but stopping to know them, and to note them down 
in the shorthand of his sketchbook." "The goal," he explained, "is not making art. It is living a life. . . . It is the trace of those who have led their lives" (Spirit, 17, 198). Stuart Davis recalled the sheer joy of "running around and drawing things in the raw," citing in particular student excursions to "Chinatown; the Bowery; the burlesque shows; the Brooklyn Bridge; McSorley's Saloon on East $7^{\text {th }}$ Street; the Music Halls of Hoboken; the Negro Saloons; [and] . . . the canal boats under the Public Market."26 Such diversity recalled for him the sites Whitman had himself encountered on his urban rambles and strengthened Davis's desire to express in his art "the thing Whitman felt."27 Sloan agreed, noting that Whitman's "descriptive catalogues of life" helped "interest me in the details of life around me" (qtd. in Kwiat, 620). ${ }^{28}$

In an interview later in life, Davis spoke effusively about the intense personal value he gained from Henri's emphasis on writers like Whitman. "When Henri spoke of writers," Davis recalled, "what he did was to inspire a desire on the part of the listener to go out, to look up all this stuff and to get involved with it. There was nothing like that in any other art school in New York, in Europe, or anywhere else so far as I know. It was a unique thing which inspired the students with the thought that they were somebody, that they were worth something, and that they should go out and try to use this awareness, try to develop it as opposed to just going and learning a certain discipline." ${ }^{29}$ With his inspiring rhetoric and can-do attitude, Whitman provided a muchneeded boost to artists' often tenuous self-esteem and lack of confidence in their own potential. The personality that dominated Whitman's verse was warm, quirky, vigorous, and self-deprecating; freed from the constraints and pompous expectations governing conventional society, it seemed refreshingly spirited and reassuring.

In addition to his colloquial speech and inviting personal manner, Whitman attracted widespread attention with the startling physicality and athleticism of his verse. This self-appointed "poet of the Body," who daringly confronted his reader "hankering, gross, mystical, nude," seemed at times to fling himself right out from the pages of his book and to assume physical form, to transcend the conventional role of author, and to become instead a friend and companion to the reader: "My left hand hooking you round the waist, / My right hand pointing to landscapes of continents and the public road" ( $L G, 48,47,83)$. As he explained in "So Long!," "Camerado, this is no book, / Who touches this touches a man" $(L G, 505)$. That exuberant sense of bodily presence accorded well with the mounting clamor for greater personal and sexual freedom that was rapidly transforming the social and political landscape in the first decades of the twentieth century. For his part and in line with the striking, gestural quality of Whitman's verse, Henri urged artists to assert themselves physically in their art. Rejecting the tight surfaces 
and brushless effects favored by the Academy, he advocated instead for an expansive and broadly gestural art to serve as an important marker of the presence and personality of the artist-maker. "Strokes carry a message whether you will it or not," he counseled: "The brush stroke at the moment of contact carries inevitably the exact state of being of the artist at that exact moment into the work" (Spirit, 71, 16). If the brushstroke signified the residue of the artist's body living on in the fictive space of the work, these enriched surface effects served also to validate the sincerity and authenticity of the art-making process. "Let your painting show the vibration of breathing," Henri advised: "Get the full swing of your body into the stroke" (Spirit, 245, 74). ${ }^{30}$

In advocating for a lively, gestural mode of painting, Henri was advocating as well for a vibrant art of movement and inflection. Henri often drew attention to the gestural surfaces of painters like Velasquez, Hals, and Manet, whom he greatly admired, but it was the gestural and highly expressive movements of the American dancer Isadora Duncan that most stirred his imagination. "Back of her gesture I see a deep philosophy of freedom, and of dignity, of simplicity and of order," he exclaimed. "She is one of the prophets who open to our vision the possibility of a life where full natural growth and full natural expression will be the aim of all people." Like many who saw her perform, Henri sensed in the intoxicating and transgressive qualities of her dance nothing less than "the great voice of Walt Whitman." ${ }^{11}$ The British theatre designer Gordon Craig spoke for many of his generation when he exclaimed, "Walt in a book is alive-but Walt walking, dancing, is LIFE." 32 If Duncan could transform the spirit of Whitman's verse into dance, Henri was confident he and his students could translate it into paint. "Pretend you are dancing or singing a picture," Henri advised his students: "Put activity into it" (qtd. in Life, 59, 72). With complementary tickets supplied by Mary Fanton Roberts, editor of The Craftsman, Henri's students were often seen sketching in the front row at the dancer's New York performances (Life, 95-96). ${ }^{33}$

John Sloan and William Walkowitz, who studied with Henri at the Ferrer Center, were among those to probe the Whitmanesque qualities of Duncan's dance in their art. In 1916 Sloan included one of his etchings of Duncan in the background of his portrait of noted Whitman biographer Horace Traubel (see reproduction on the back cover). Sloan's pairing of Duncan and Traubel reified their mutual commitment to the life-giving force of Whitman's verse. Traubel was perhaps best known as the editor of The Conservator, the principal organ of the Walt Whitman Fellowship International. Sloan and Henri both knew Traubel personally, and just the year before sitting for Sloan's portrait, Traubel had reprinted selections from Henri's article, "My People," in two successive issues of The Conservator. ${ }^{34}$ Still, when Traubel invited 
Henri to speak at the annual Whitman Fellowship meeting in New York, Henri politely declined. Although no stranger to public speaking, Henri indicated that he preferred to celebrate Whitman on his own terms and only when the mood struck. "I celebrate the debt I owe to Whitman many joyous times - they are happy moments [;] I await and I welcome their coming without regard to time or place." ${ }^{35}$

Whatever reservations Henri had about speaking publicly at the Whitman Fellowship disappeared entirely in the classroom. Future art critic Helen Appleton Read, a Smith College graduate and former student of William Merritt Chase, recalled her delight that in Henri's class she "heard Walt Whitman for the first time unblushingly discussed in a mixed gathering." 36 Although Henri was not known for encouraging artists to explore the kind of explicit sexual content that so shocked readers of Whitman's verse, neither did he try to dissuade artists from exploring sexual matters in their art. The freedom to choose far outweighed any prohibitions against it. Sloan's sympathy for the plight of prostitutes and sensuous treatment of couples in bed, as in the lyrical

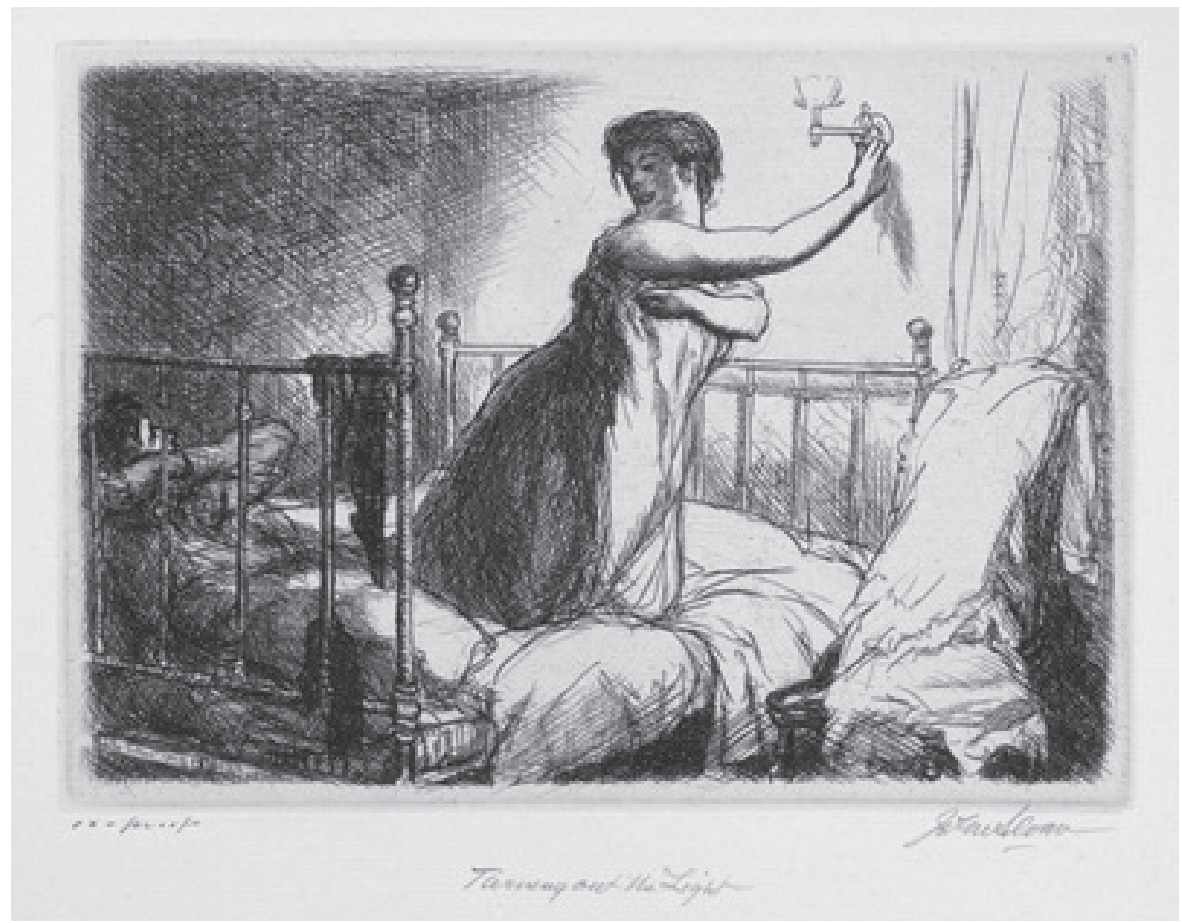

Figure 2. John Sloan, Turning out the Light, 1905. John Sloan (1871-1951). Steel-faced copper plate etching, ink on paper, $9 \times 12$ in. $(22.9 \times 30.5 \mathrm{~cm})$. Delaware Art Museum, Gift of Helen Farr Sloan, 1963. (C) 2011 Delaware Art Museum / Artists Rights Society (ARS), New York. 
Turning out the Light, 1905 (Figure 2), both radical subjects by turnof-the-century standards, bear witness to both Henri's tolerance and Whitman's poetic celebration of "the flesh and the appetites" $(L G, 53)$.

In the classroom Henri's manner was focused and empowering. In striking contrast to the staged theatrics of his former colleague, William Merritt Chase, Henri approached teaching as an intimate and enabling conversation between friends. Rockwell Kent described Henri's critiques as "earnest . . . a at times, impassioned [,] and . . . almost invariably personal - that is, directed to one student at a time." ${ }^{37}$ Still, many students found Henri's comments so stimulating that they followed him around the room to listen in on his conversations with others (Life, 59). "I teach straying from me, yet who can stray from me?" Whitman advised: "I follow you whoever you are from the present hour, / My words itch at your ears till you understand them" $(L G, 85)$. For Henri as for Whitman the success of the individual was integrally connected to the success and well-being of the group. Whitman's great passion, as Ed Folsom and Kenneth M. Price have noted, "was for a democracy that celebrated the self yet sang the ensemble, a democracy

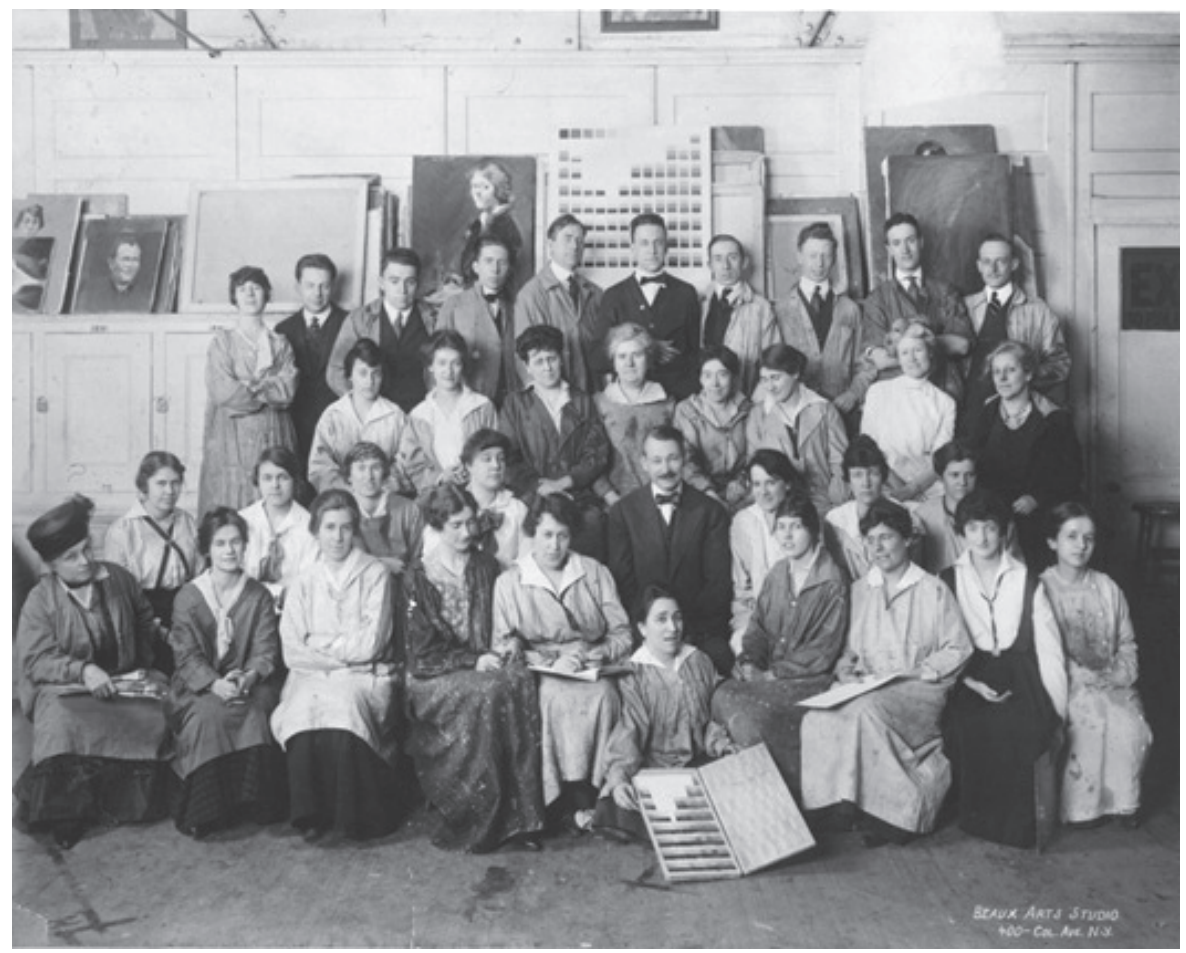

Figure 3. Robert Henri's Art Students League painting class, New York, ca. 1916. Robert Henri is seated in the center of the second row. Courtesy of Marian Wardle. 
that worshipped the individual and the communal, that indeed defined democratic individuality as the ability to imagine and empathize with the vast variety of other individualities that composed the nation." 38 The communal spirit that suffused the classroom radiates outward from the many group photographs Henri sat for with his students. Typical is a photograph in which a smiling Henri sits surrounded by a group of some three dozen male and female students from the Art Students League (Figure 3). Attired in their paint smocks, some holding the implements of their craft, the group is huddled together, their bodies relaxed and often touching the person next to them, their faces registering warmth, openness, and the pleasure of extended human contact.

The sense of community that pervaded Henri's classroom characterized much of the art produced by his students and those in his immediate circle as well. Whether that community involved a group of Jewish merchants and their customers on the Lower East Side (as in George Luks, Hester Street, 1905, The Brooklyn Museum), a gathering of gaily-clad spectators enjoying the new urban entertainments (as in William Glackens, Hammerstein's Roof Garden, ca. 1901, The Whitney Museum of American Art), or friends sharing the joys of a communal meal, the celebration of community registered as a leit motif throughout much of the art produced by Henri and his circle. This was particularly true in the art of John Sloan. Memory (Figure 4), for example, completed in 1906, shortly after the artist joined Henri in New York, represents Henri and his wife Linda, a former student who had died the previous year, enjoying an intimate evening together with the Sloans. The men draw while Linda reads aloud from a book and Sloan's wife Dolly gazes steadily out at the viewer. With the exception of Dolly who seems to await the next game of cards, each of those present is absorbed in his/ her own pursuit-the men drawing, Linda reading - while simultaneously enjoying the company and camaraderie of the group. Even Sloan's self-representation, the first of many over his long career, manifests elements of Whitman's engaged artist-participant. Sloan's dark features and three-quarter pose make him the strongest and most expressive of the work's four figures, a visual trope for Whitman's participating "I." 39

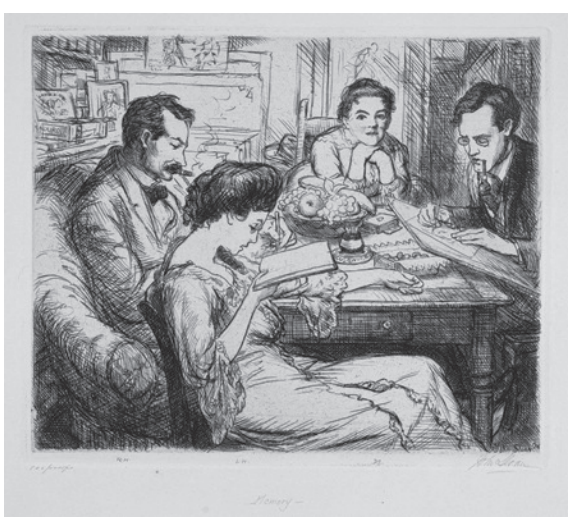

Figure 4. John Sloan, Memory, 1906. John Sloan (1871-1951). Etching on paper, 7 $1 / 2 \times 9$ in. $(19.1 \times 22.9 \mathrm{~cm})$. Delaware Art Museum, Gift of Helen Farr Sloan, 1998. (C) 2011 Delaware Art Museum / Artists Rights Society (ARS), New York. 
Henri's commitment to what he termed the "great brotherhood" of artists assumed its most public dimension in his pioneering efforts to stimulate the promotion and popularization of American art through independent exhibitions (Spirit, 18). Above all, Henri championed the concept of jury-free exhibitions where the exhibiting artists rather than a select group of often conservative jurors assumed responsibility for the selection and display of each artist's work. Henri had experienced firsthand the personal and professional consequences of having his art rejected by the restrictive exhibition policies endorsed by large, hierarchical organizations like the National Academy. In advocating for smaller, more democratically structured exhibitions, Henri was especially committed to helping artists whose work fell outside the artistic mainstream. One of his first public ventures in this regard was the collaborative staging of the 1908 exhibition "The Eight" at the Macbeth Galleries. The exhibition, with its focus on the works of eight artists, each with full autonomy to choose the works he would exhibit and how they would be displayed, garnered critical and popular success. Two years later Henri helped plan the larger and more comprehensive Exhibition of Independent Artists. For this, he and his fellow artists eschewed the common practice of hanging artists' works according to a hierarchical scheme that favored the work of established artists. Instead, they employed the far more democratic practice of hanging the works of all the exhibiting artists in strict alphabetical order. In planning the exhibition, Henri described it as "an opportunity for individuality, an opportunity for experimenters. ... Freedom to think and to show what you are thinking about, that is what the exhibition stands for."

In the first volume of With Walt Whitman in Camden, Traubel's insightful and highly personal biography of the poet published in 1906, Whitman outlined his own opposition to some of the hierarchical practices Henri opposed, especially the practice of hanging works "on the line." "That line in a conventional art gallery!" Whitman exclaimed; "I'm not so sure of it, my hearty. I wonder if Leaves of Grass would be hung on the line if the galleries had their way about it? - on the line or on a scaffold?" "4l As an avid consumer of all that was written about the poet, Henri was no doubt familiar with Whitman's biting critique of the exhibition practices favored by the Academy. At the very least Whitman's observations confirmed the poet's stature as an astute observer of the visual arts practices of his day. More importantly, Whitman's remarks graphically reinforced Henri's own reform instincts. By distancing himself and his verse from the very practices Henri was now determined to change, Whitman soundly affirmed both the integrity of the exhibition process and his support for the autonomy of the exhibiting artist.

In 1911 Henri joined the faculty of the Ferrer Center, a major hub of anarchist activities and a thriving center for progressive education. 
Here, for the first time, the artist's pedagogical ideas reverberated within the ranks of a group of activists and educators who fully shared his Whitmanian enthusiasm. The Ferrer Center was dedicated to the memory of Spanish anarchist and educator Francisco Ferrer and, in the words of historian Paul Avrich, was "a place where cultural experimentation mingled with social insurgency." ${ }^{42}$ Whitman's democratic egalitarianism, his willful flaunting of society's norms ("I wear my hat as I please indoors or out" $[L G, 47])$, and his unwavering faith in the power and integrity of the individual accorded well with the group's social, political, and artistic goals. Leonard Abbott, one of the school's leading figures, hailed the poet as an "emancipator" and judged Leaves of Grass "a veritable Scripture of the modern radical movement." ${ }^{\text {"43 }}$ Whitman's portrait hung in the main lecture hall alongside those of others of the school's philosophical forebears, including Tolstoy, Ibsen, Thomas Ingersoll, Thomas Paine, and William Morris; one of the most popular lecturers at the Center was Henri's old friend, Sadakichi Hartmann, who often read from Whitman's verse. ${ }^{44}$ In 1919 , the centennial of Whitman's birth, the school's journal, The Modern School, edited by Henri student Carl Zigrosser, devoted an entire issue to assessing Whitman's life and the national and international expansion of his legacy. ${ }^{45}$

Henri joined the Ferrer Center at the personal invitation of Emma Goldman. In her autobiography Goldman recalled meeting Henri in New York in the fall of 1911 following one of her lectures. "I had heard of Henri," she wrote, "had seen his exhibitions, and had been told that he was a man of advanced social views." Henri had also heard of Goldman. The previous year, while in Toledo, he had attended one of her lectures, after which he purchased her book, Anarchism and Other Essays, which he read on the train back to New York. Henri told Goldman that he enjoyed her magazine, Mother Earth, "especially the articles on Walt Whitman." ${ }^{\text {W6 }}$ At the Ferrer Center Henri's course proved immensely popular. Leonard Abbott termed it "one of the best, if not absolutely the best [art class], in the entire country." ${ }^{47}$ A measure of its success can be gauged by the strength and diversity of the students it attracted, among them landscape painter (and eventual illustrator of the 1936 Heritage Press edition of Leaves of Grass) Rockwell Kent; future Dadaist Man Ray; cubist Max Weber; expressionists Abraham Walkowitz and Ben Benn; social-realist Moses Soyer; and textile artist Marguerite Zorach and her sculptor husband William. Also in attendance was sculptor and poet Adolf Wolff. In 1913, Wolff's poem, "Walt Whitman," composed in Abbott's literature class and published in the inaugural issue of Glebe, echoed the sentiments of many at the school. With youthful exuberance, Wolff likened Whitman to "a mountain, mighty, vast and wild" and praised his verse as "A clarion-call to freedom, / A gesture of revolt, / . . . / A declaration of the right of all / To live, to love, to dare and to do." ${ }^{8}$ 
As an artist, Henri devoted much of his career to painting portraits of those he admiringly called "my people." "The people I like to paint," he wrote in The Craftsman, "are 'my people,' whoever they may be, wherever they may exist, the people through whom dignity of life is manifest." ${ }^{\text {"49 }}$ Like his well-known portrait of Eva Green, 1907 (Figure 5), a young African-American girl whom he probably met on the streets of New York, Henri's portraits celebrate the dignity, humanity, and respect of those often overlooked by mainstream American society, including children, the infirm, the elderly, immigrants, African Americans, Asian Americans, and Native Americans. Whitman, too, celebrated the country's racial and ethnic diversity, and in "Song of Myself," boldly proclaimed, "In all people I see myself, none more and not one a barleycorn less" ( $L G, 47)$. Whitman was similarly entranced by the potent power of portraiture: "Ah! What tales might those pictures tell if their mute lips had the power of speech!," he once exclaimed upon perusing a display of photographic portraits at Plumbe's Daguerreotype Gallery. ${ }^{50}$

Henri's portraits, like his representation of the youthful Eva Green, bore witness to the lively brushwork and broad, gestural effects that were the hallmark of his teaching, but they were hardly daring in either format or expressive qualities. Even as Henri encouraged his students to seek out and become conversant with the modernist practices celebrated in the Armory Show of 1913 and promoted in small, independent galleries

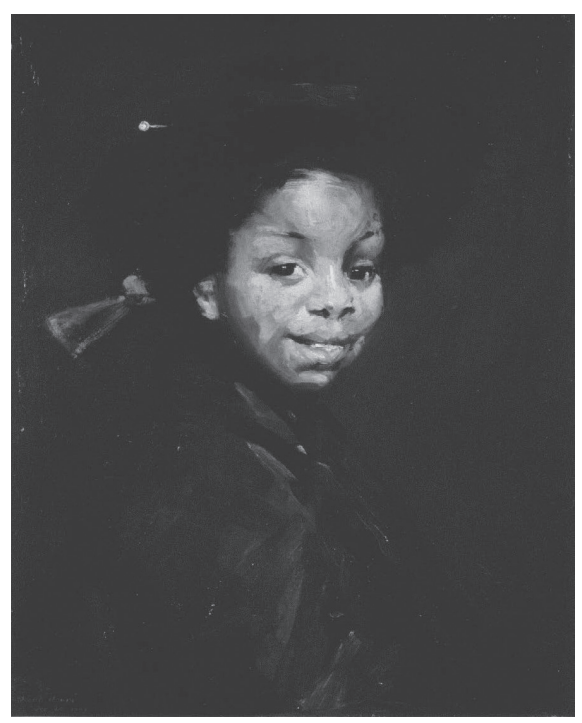

Figure 5. Robert Henri, Eva Green, 1907. Oil on canvas, $241 / 8 \times 201 / 4$ in. M59.45. Roland P. Murdock Collection, Wichita Art Museum, Wichita, Kansas. like Alfred Stieglitz's 291 Gallery, his own art remained anchored in far more conservative and traditional art practices. Following Henri's death, Helen Appleton Read offered an astute appraisal of the disparity between Henri's progressive teaching practices and the conservative nature of his own artistic production. "What was the magic," she asked, that allowed Henri's students and many of the critics to regard his art as possessing the same "crusading spirit" as his teaching: "As we look at them now [his paintings] seem inherently conservative, savoring more of Whistler and Manet's refinements than Courbet's exuberant humanism." With the advantage of hindsight, she proffered: "Even then, I suspect, it was the aura of 
Henri's personality and the ideals he was battling for that lent them a radicalism that they did not in actuality possess" (Read, 9). ${ }^{51}$

Like Whitman, the self-proclaimed "bard of personality," Henri tapped the resources of his own personality to persuasively restructure the pedagogical experiences of large numbers of American artists in the early decades of the twentieth century $(L G, 22)$. Henri's ability to frame the goals of the twentieth-century American artist through the lens of Whitman's verse helped shift the artistic discourse decisively away from the emphasis on correct drawing, controlled surface effects, and historical subject matter valued by the Academy. In Henri's classroom the discussion focused instead on matters of identity, the self, freedom of expression, and the relationship between the individual and the community. Together these tools provided students with a rich constellation of referents with which to fashion their own individual responses to the social, political, and artistic changes that were rapidly transforming the American cultural landscape. Artists as diverse as Edward Hopper, John Sloan, Isabel Bishop, Florine Stettheimer, Stuart Davis, and Joseph Stella, each of whom commenced their artistic careers under Henri's tutelage, continued to draw strength from Henri's ideals long after their classroom sessions had ended.

The publication in 1923 of The Art Spirit, a compilation of Henri's classroom commentaries, helped strengthen his reputation and broaden knowledge of his objectives among current and future generations of artists. The book's directness, its rambling and fragmentary structure, and even its language seemed aligned with the optimistic and colloquial nature of Whitman's verse. In the introduction to the 1921 Modern Library edition of Leaves of Grass, one of the many new editions of Whitman's verse to appear in the interwar years, poet Carl Sandburg characterized the work as "a book to be owned, kept, loaned, fought over, and read till it is dog-eared and dirty all over." 52 The same could be said of The Art Spirit. Since its publication, The Art Spirit's bracing tone and inspiring objectives have captured the imaginations of scores of individuals across multiple generations and artistic persuasions. In "Poets to Come," Whitman reminded his reader "Not to-day is to justify me and answer what I am for, / But you, a new brood, native, athletic, continental, greater than before known, / Arouse! for you must justify me" $(L G, 14)$. Henri's place among this "new brood" is indisputable, sustained in large part by his continuing efforts to "justify" the poet to an ever-expanding audience of American artists.

\section{University of Missouri-St. Louis}




\section{NOTES}

1 Robert Henri quoted in Emma Goldman, Living My Life (New York: Alfred A. Knopf, 1931), 1:377-378.

2 Walt Whitman, Leaves of Grass: Comprehensive Reader's Edition, ed. Sculley Bradley and Harold W. Blodgett (New York: New York University Press, 1965), 4. Hereafter, LG.

3 John Burroughs, Walt Whitman: A Study (1896; rpt. New York: AMS Press, 1969), 235.

4 Joseph Kwiat was the first to explore Henri's commitment to Whitman in his groundbreaking article, "Robert Henri and the Emerson-Whitman Tradition," PMLA 71 (September 1956), 617-636. Among recent efforts at locating Henri's Whitmanic sympathies within the broad outpouring of support for Whitman in the first decades of the twentieth century, especially perceptive are Alan Trachtenberg, "Walt Whitman: Precipitant of the Modern," in The Cambridge Companion to Walt Whitman, ed. Ezra Greenspan (New York: Cambridge University Press, 1995), 194-207, and Matthew Baigell, Artist and Identity in Twentieth-Century America (New York: Cambridge University Press, 2001), 11-25. My own scholarship into Whitman's reception among early twentieth-century artists, including Henri, follows in this vein. See especially Looking into Walt Whitman: American Art 1850-1920 (University Park, PA: Pennsylvania State University Press, 2006), and “'I Sing the Body Electric': Isadora Duncan, Whitman, and the Dance," in The Cambridge Companion to Walt Whitman, 166-193.

5 Walt Whitman, An American Primer, ed. Horace Traubel (1904: rpt., Stevens Point, WI: Holy Cow! Press, 1987), 34.

6 Henri was the only member of his family to adopt the surname Henri. His parents took Lee as their surname; his brother became Frank Southrn. See William Innes Homer, Robert Henri and His Circle (Ithaca: Cornell University Press, 1969), 10-17.

7 On the growing internationalism of Whitman's appeal see especially Betsy Erkkila, Walt Whitman Among the French: Poet and Myth (Princeton: Princeton University Press, 1980); Walter Grünzweig, Constructing the German Walt Whitman (Iowa City: University of Iowa Press, 1995); and Gay Wilson Allen and Ed Folsom, eds., Whitman $\mathcal{E}$ the World (Iowa City: University of Iowa Press, 1995).

8 Seton, the future founder of the Boy Scouts of America, credited Henri's developing enthusiasm for Whitman with providing the basis for a twenty-three verse poem written in dialogue, which he referred to as his "Whitman dream." Now lost, the poem presumably served as a prelude to a later article he published in the journal Recreation 6 (June 1897), 480. Entitled "An Interview with Whitman's Spirit," this humorous chant emulated Whitman's effusive style to praise the poet for his progressive ideas toward nature and the female form. On Seton's dream, see Ernest Thompson [Seton] to Robert Henri, December 22, 1894, Robert Henri Archive, Beinecke Rare Book and Manuscript Library, Yale University, New Haven, CT. On Whitman's interest in Millet, see my Looking into Walt Whitman, 76-81. On subsequent visits to Paris, Henri frequented the Closerie des Lilas, the café favored by the Symbolists, where Whitman was a prime topic of conversation. See Bennard B. Perlman, Robert Henri: His Life and Art (New York: Dover, 1991), 34-35; hereafter, Life.

9 Whitman arrived in the gritty, industrialized city of Camden in May 1873 to be by the bedside of his dying mother. Following the decline of his own health, he stayed on, rooming first with his brother George, and then, in 1884, purchasing an 
extremely modest structure with no furnace, at 328 Mickle Street. On Whitman's life in Camden, see William Pannapacker, "Whitman's Philadelphia and Whitman's Camden: Retrospect and Prospect," Mickle Street Review 17/18 (2005), micklestreet. rutgers.edu/.

10 “The Poet's Career," Philadelphia Press (March 27, 1892). In another article, the Press lamented that "American literature has lost in Walt Whitman its most significant figure and its most picturesque original personality." "Walt Whitman," Philadelphia Press (March 27, 1892).

11 Gay Wilson Allen, The Solitary Singer (Chicago: University of Chicago Press, 1985), 541.

12 Thomas Eakins and his colleague, sculptor William O'Donovan, were among twenty-six honorary pallbearers. See "Walt Whitman's Funeral," Philadelphia Times (March 30 and 31, 1892); "Walt Whitman Dead," Philadelphia Times (March 27 1892), 2; "Walt Whitman Dead," Philadelphia Press (March 27, 1892), 1; and "Whitman Buried as He Wished," Philadelphia Press (March 31, 1892). See also Scott Giantvalley, Walt Whitman, 1838-1939: A Reference Guide (Boston: G, K. Hall \& Co., 1981), 111-118.

13 McCarter recommended Henri for the position. William Yarrow and Louis Bouche, eds., Robert Henri: His Life and Works (New York: Boni \& Liveright, 1921), 23. On McCarter's and Murray's ties to Whitman, see my Looking into Walt Whitman, 74-76, and 122-138.

14 Sadakichi Hartmann, Conversations with Walt Whitman (1895: rpt. New York: Gordon Press, 1972), 3. Following his initial meeting with the poet in 1884, Hartmann made many return visits to Whitman's home, and in 1887, after relocating to Boston, attempted unsuccessfully to establish a Whitman society in New England. See George Knox, The Whitman-Hartmann Controversy (Bern: Herbert Lang, 1976).

15 Having worked part time at a local bookstore, Sloan owned copies of Leaves of Grass and Good-bye and Hail Walt Whitman: At the Graveside of Walt Whitman, a volume published in conjunction with the poet's funeral, and would soon acquire and give to Henri a more recent edition of Leaves of Grass than the 1884 printing of the 1881 edition he then owned. Information on the first discussion between Sloan and Henri and on the Whitman books in Sloan's library is from my conversation with Helen Farr Sloan, October 8, 1987. See also Bennard B. Perlman, Painters of the Ashcan School: The Immortal Eight (New York: Dover, 1979), 41; and Perlman, Robert Henri: His Life and Art, 25. Sloan's copy of Good-bye and Hail Walt Whitman is in the John Sloan Collection at the Delaware Art Museum, Wilmington, Delaware. Neither Sloan's nor Henri's copies of Leaves of Grass survive.

16 John Sloan, “An Artist's Words: Some Unpublished comments by John Sloan, 1944-50," in James Kraft, Fohn Sloan: A Printmaker (Washington, DC: International Exhibitions Foundation, 1984), 20. On the authors the group discussed, see Homer, Robert Henri and His Circle, 68-84.

17 Walt Whitman, "Something About Art and Brooklyn Artists," New York Evening Post (February 1, 1851), in The Uncollected Poetry and Prose of Walt Whitman, ed. Emory Holloway (Gloucester, MA: Peter Smith, 1972), 1:237.

18 John Sloan, "John Sloan Discussing Robert Henri," in fohn Sloan/Robert Henri: Their Philadelphia Years (1886-1904) (Philadelphia: Moore College of Art Gallery, 1976), 27. 
19 Robert Henri, "A Practical Talk to Those Who Study Art," Philadelphia Press (May 12, 1901), 6. The lecture was reprinted in revised form in Robert Henri, The Art Spirit (1923; rpt. Philadelphia and New York: J. B. Lippincott Co., 1960), 78-87; hereafter, Spirit.

20 Whitman's personality was the focus of the May 1898 meeting of the Boston Walt Whitman Fellowship International; "Personality in Whitman," Poet-Lore, 10 (January-March 1898), 113-114. Although not published until much later, another important early assessment of Whitman's personality, written by a South African, is Jan Christian Smuts, Whitman: A Study in the Evolution of Personality (Detroit: Wayne State University Press, 1973). For the shifting ways in which personality has been defined see Raymond Williams, Keywords: A Vocabulary of Culture and Society (New York: Oxford University Press, 1976), 194-197. See also Warren I. Susman, Culture as History: The Transformation of American Society in the Twentieth Century (New York: Pantheon Books, 1984), 271-285.

21 On the biographical emphasis of the writings on Whitman see especially, M. Jimmie Killingsworth, The Growth of Leaves of Grass: The Organic Tradition in Whitman Studies (Columbia, SC: Camden House, 1993), 9-45; see also, Charles B. Willard, Walt Whitman's American Fame (Providence: Brown University Press, 1950).

22 Carleton Noyes, An Approach to Walt Whitman (Boston: Houghton Mifflin, 1910), 17, 213. The books on which Noyes sought Henri's assistance were The Enjoyment of Art (1903) and The Gate of Appreciation: Studies in the Relation of Art to Life (1907). On Whitman's reception among Harvard poets, see Kenneth M. Price, Whitman and Tradition: The Poet in His Century (New Haven: Yale University Press, 1990).

23 On the profound shifts transforming early twentieth-century American culture, see especially Allan Antliff, Anarchist Modernism: Art, Politics, and the First American Avant-Garde (Chicago: University of Chicago Press, 2001); Robert Crunden, Ministers of Reform: The Progressives' Achievement in American Civilization, 1889-1920 (New York: Basic Books, 1982) and Body E Soul: The Making of American Modernism (New York: Basic Books, 2000); and Jackson Lears, No Place of Grace: Antimodernism and the Transformation of American Culture, 1880-1920 (New York: Pantheon Books, 1981).

24 Robert Henri in "Wm. M. Chase Forced out of N.Y. Art School: Triumph for the 'New Movement' Led by Robert Henri," New York American (November 20, 1907), cited in Perlman, Robert Henri: His Life and Art, 80. See also Homer, Robert Henri and His Circle, 133.

25 Robert Henri, "Progress in Our National Art Must Spring from the Development of Individuality of Ideas and Freedom of Expression: A Suggestion for a New Art School," The Craftsman 15, no. 4 (January 1909), 392, 387, 389.

26 Stuart Davis quoted in Rebecca Zurrier, Picturing the City: Urban Vision and the Ashcan School (Berkeley: University of California Press, 2006), 123.

27 Stuart Davis quoted in Lowery Sims, Stuart Davis: American Painter (New York: Metropolitan Museum of Art, distributed by Harry N. Abrams, 1991), 151.

28 In his diary Sloan describes several instances where his reading of Leaves of Grass prompted him to immediately set out to explore the city on foot. See especially John Sloan, Fohn Sloan's New York Scene, ed. Bruce St. John (New York: Harper \& Row, 1965), 314, 428. 
29 Stuart Davis quoted in Garnet McCoy, “The Artist Speaks: Reaction and Revolution 1900-1930," Art in America 53 (August 1965), 70.

30 Whitman, too, valued the physical connection between the artist and the animated surface of his work, no doubt because a broadly worked surface seemed to him an appropriate correlate to the lively, unmediated nature of his own work. As he informed Eakins, "Walt Whitman who himself treats everything broadly, has to be treated broadly in turn." In scrutinizing the many portraits made of him from life Whitman would often comment on each work's surface treatment. He dismissed the sculpted bust made by Eakins' colleague, William O'Donovan, for example, as "too smoothified," too finished looking, and he criticized O'Donovan for being "too particular," for not grasping "the generals." On the other hand, he offered elaborate praise for the far cruder work of the self-trained Sidney Morse. Dashed off in the back yard of Whitman's Camden home, Morse's bust, with its turned head and irregular surface treatment, was celebrated for its "rugged power," its unconventionality, and its overt rejection of the classicizing ideals of the academy. For Whitman, as for Henri, the "livingness" of the work of art found physical expression far less in its formal "correctness" than in its lively surface treatment. See With Walt Whitman in Camden (various publishers, 1906-1996), 8:371;2:405. For more on the two Whitman busts, including photographs, see my Looking into Walt Whitman, 105-109, 125-127.

31 Robert Henri, "Isadora Duncan and Walt Whitman," Dionysian 1, no. 1(1915), n.p.

32 Gordon Craig quoted in Francis Steegmuller, "Your Isadora": The Love Story of Isadora Duncan and Gordon Craig (New York: Random House and the New York Public Library, 1974), 63. See also my "II Sing the Body Electric': Isadora Duncan, Whitman, and the Dance," 166-193.

33 Duncan's troupe of young dancers were in turn Henri's guests at exhibitions of his students' work.

34 Selections of his article appeared in the following issues: (May 1915), 40-41, 26, and (June 1915), 49, 56-57. Henri subscribed to The Conservator.

35 Robert Henri to Horace Traubel, May 23, 1915, Horace Traubel Papers, Box 76, Library of Congress, Washington, DC. Traubel had been apprised of Henri's interest in Whitman as early as 1907, when Socialist Charles Wisner Barrell identified him in a letter to Traubel as "a wonderfully fine artist - a big man in every sense of the word." Equally important, Barrell noted that Henri had "traded off a deluxe set of Browning's works for a copy of Leaves of Grass," making him "one of your sort." Charles Wisner Barrell to Horace Traubel, June 14, 1907, Horace Traubel Papers, Box 52, LC. For Barrell's article on Henri, see Charles Wisner Barrell, "Robert Henri - 'Revolutionary,"” The Independent 64 (June 25, 1908), 1431.

36 Helen Appleton Read, Robert Henri (New York: Whitney Museum of American Art, 1931), 10.

37 Rockwell Kent, It's Me O Lord (New York: Dodd, Mead \& Company, 1955), 81.

38 Ed Folsom and Kenneth M. Price, Re-Scripting Walt Whitman: An Introduction to His Life and Work (Malden, MA: Blackwell Publishing, 2005), ix.

39 The table around which the four gather had been a staple of Henri's Philadelphia studio. Henri brought it with him when he moved to New York and later presented it to Sloan, who commented on the many happy memories associated with it. See Sloan, fohn Sloan's New York Scene, 40. A few years before, in Edges, a roman à clef 
by Alice Woods (an art student at the New York School of Art where Henri was then teaching), the main character, an artist studying in Paris, who is modeled on Henri, is disturbed to discover that a young, red-haired woman (both Henri's wives had red hair) had appropriated his much-beloved copy of Leaves of Grass while he was out sketching. The novel concludes with the artist and his "Whitman girl" kissing openly in the Forest of Fontainebleau, the site where Henri had discussed Whitman with Seton. See Alice Woods, Edges (Indianapolis: Bowen-Merrill Company, 1902), 1-3, and 175; see also Perlman, Robert Henri: His Life and Art, 53-54. Sloan's etching is also in "memory" of Linda Henri.

40 Robert Henri, "The New York Exhibition of Independent Artists," The Craftsman 18 (May 1910), 160. See also Elizabeth Milroy, Painters of a New Century: The Eight $\&$ American Art (Milwaukee: Milwaukee Art Museum, 1991). It is not well known that as Henri and members of The Eight were considering a sequel to the Macbeth Gallery exhibition, they were approached by Whitman enthusiast Marsden Hartley who was eager to show them some of his recent landscape paintings. While Maurice Prendergast and Sloan were favorably inclined toward the work, Sloan also expressed misgivings about both Hartley's mysticism and his exaggerated handling of clouds, which he disparagingly likened to "tinted buckwheat cakes" (Sloan, fohn Sloan's New York Scene, 303, 302). When Alfred Stieglitz offered to exhibit Hartley's paintings at 291 in what was to be the artist's first major solo exhibition, Hartley sought no future contact with Henri or his group. What at first glance may seem like little more than a footnote in the history of American modernism provides, in fact, a fascinating window into the competing and often conflicting responses to Whitman that characterized this first generation of twentieth-century American artists. In seeking a compatible group with which to align himself, Hartley was doubtless attracted by Henri's pedagogical endorsement of Whitman's emphasis on the self and freedom of expression. But Hartley's Whitman was the mystical and homoerotic bard of the Calamus poems, not the platonic poet of democracy and the city. Although Henri was far more committed to Whitman than was Stieglitz at this time, the latter proved more receptive to Hartley's mystically-inspired nature studies. If the protean nature of Whitman's verse constituted one of its most attractive features, its manifestations in paint did not always assure acceptance or even recognition among fellow travelers. A few years later Robert Coady, an activist supporter of the democratic Whitman and the boisterous publisher of The Soil, one of the period's most experimental little magazines, would demonstrate a similar lack of understanding when he too failed to grasp the Whitmanic bond he shared with Hartley, denigrating one of the latter's cosmic abstractions as inferior to a child's collage. See Robert Coady, The Soil (March 1917), 138ff. For more on Hartley's early interest in Whitman, see my Looking into Walt Whitman, 143-164.

41 Quoted in Horace Traubel, With Walt Whitman in Camden, 1:266.

42 Paul Avrich, The Modern School Movement: Anarchism and Education in the United States (Princeton: Princeton University Press, 1980), 138.

43 Leonard D. Abbott, "Walt Whitman and His Influence in American Poetry," Poetry Review 1 (October 1912), 473, 475.

44 The Ferrer Center also hosted Weda Cook singing musical renditions of Whitman's poems. Cook had often sung for Whitman and was the subject of Thomas Eakins's imposing visual tribute to Whitman, The Concert Singer, 1890-1892. See my Looking into Walt Whitman, 127-139.

45 The Modern School, Walt Whitman Number (April-May 1919). 
46 Goldman, Living My Life, 2:528-529, 1:377-378. Goldman had originally intended to call her journal The Open Road after Whitman's poem, "Song of the Open Road," but was prevented from doing so when a Colorado journal of the same name threatened to sue if the name was not changed.

47 Leonard D. Abbott, "The Ferrer School in New York," Everyman 10 (December 1914), 8.

48 Adolf Wolff, "Walt Whitman,” The Glebe 1, no. 1 (September 1913), 66.

49 Robert Henri, “My People," The Craftsman 27, no. 5 (February 1915), 459.

50 Walt Whitman, "Visit to Plumbe's Gallery," in The Gathering of the Forces, ed. Cleveland Rogers and John Black (New York and London: G. P. Putnam's Sons, 1920), 2:114.

51 Particularly pertinent in this regard is Henri's highly conservative portrait of Emma Goldman, completed in 1915 just after she was released from jail. The halflength painting represents the fiery speaker and birth control advocate sumptuously attired in a dark dress with a ruffled bodice and a prominently placed brooch. The flamboyant brushwork and dazzling surface effects do nothing to blunt the sense that the sitter bears a closer resemblance to a fashionable society matron than to the person Henri himself praised as "one of the world's greatest fighters for the freedom and growth of the human spirit." Robert Henri, "An Appreciation by an Artist," Mother Earth 10 (March 1915), 415. Henri's sister-in-law destroyed the painting in 1934, five years after his death. See Robert Henri: Painter (Wilmington, DE: Delaware Art Museum, 1984), 131.

52 Carl Sandburg, "Introduction to Modern Library edition of Leaves of Grass," quoted in Walt Whitman's 'Song of Myself': A Sourcebook and Critical Edition, ed. Ezra Greenspan (New York and London: Routledge, 2005), 77. 